\title{
PEMIKIRAN PENDIDIKAN ISLAM IBNU KHALDUN 1332M
}

\author{
Mhd Rasid Hamdi \\ Mahasiswa Program Pascasarjana (PPs) \\ Prodi Pendidikan Bahasa Inggris \\ UIN SUSKA RIAU \\ E.mail : rasidhamdi@gmail.com \\ Yuli Harti \\ UIN SUSKA RIAU \\ Yanti, \\ UIN SUSKA RIAU
}

\begin{abstract}
Islamic education today still needs efforts to support the growth and development of Islamic education. One of the efforts made by photographing the condition of the development of Islamic education in the era of the glory of Islam in the classical period so that many great Islamic figures and their monumental works were born. The condition of Islamic education today, which is experiencing various kinds of problems, needs to be addressed immediately by developing the knowledge of Islamic education through a series of research studies involving the study of Muslim intellectual figures from classical, medieval, to modern times today. One of the figures who take part in the world of Islamic philosophers is Ibn Khaldun who has produced many works and his existence in the field of science. The research method used in this research is library research using a qualitative research approach. The author in this case seeks to collect library data related to Ibn Khaldun's Islamic Education Thought either through books or other sources such as articles or previous studies related to the topic.
\end{abstract}

\section{Abstrak}

Pendidikan Islam dewasa ini masih perlu upaya untuk menopang tumbuh dan berkembangnya perkembangan pendidikan Islam tersebut. Salah satu upaya yang dilakukan dengan memotret kondisi perkembangan pendidikan Islam di era kejayaan Islam masa klasik sehingga banyak melahirkan tokoh-tokoh besar Islam berserta karyanya yang monumental. Kondisi ilmu pendidikan Islam dewasa ini yang mengalami berbagai macam persoalan perlu segera diatasi dengan cara menumbuhkembangkan ilmu pendidikan Islam melalui serangkaian kajian penelitian yang melibatkan kajian tokoh intelektual muslim dari zaman klasik, 
pertengahan, sampai modern sekarang ini. Salah satu tokoh yang berkiprah dalam dunia filosuf Islam ialah Ibnu Khaldun yang telah banyak menghasilkan buah karya dan eksistensinya dalam bidang keilmuan. Metode penelitian yang digunakan dalam penelitian ini adalah penelitian pustaka (library research) dengan menggunakan pendekatan penelitian kualitatif. Penulis dalam hal ini berupaya mengumpulkan data-data kepustakaan terkait Pwmikiran Pendidikan Islam Ibnu Khaldun baik melalui buku-buku ataupun sumber lain seperti artikel atau penelitian-penelitian terdahulu yang terkait dengan topik tersebut.

Kata Kunci: Pemikiran Pendidkan Islam, Ibnu Khaldun

\section{A. Pendahuluan}

Pendidikan merupakan proses membimbing, membina, mengajarkan manusia agar manusia dapat mengetahui berbagai hal, dan dapat mengetahui apa yang seharusnya dilakukan olehnya sebagai mahluk yang disebut manusia, oleh karena itu pendidikan merupakan kebutuhan setiap manusia, dengan adanya pendidikan manusia akan mampu melakukan apapun yang dia inginkan, dengan pendidikan manusia dapat mengembangkan potensi dalam dirinya serta mengembangkan akal pikirannya sehingga dalam melakukan segala sesuatu manusia tidak mengalami kesalahan yang fatal. Pendidikan terhadap manusia dipengaruhi oleh berbagai faktor yang diantaranya faktor keluarga, dan lingkungan tempat manusia hidup dan bergaul. Pendidikan yang baik akan menjadikan manusia tersebut baik pula dan sebaliknya pendidikan yang buruk akan mengakibatkan buruk pula bagi manusia yang mengalaminya.

Mengenai pendidikan banyak sekali pemikiran-pemikiran para cendikiawan mengenai pendidikan terhadap manusia baik cendikiawan Islam ataupun cendikiawan non-Islam. Pemikiran para ahli mengenai pendidikan sangat beragam, namun banyak pula kesamaan pemikiran. Namun dalam tulisan ini penulis akan menganalisa satu pemikiran pendidikan yaitu pemikiran seorang cendikiawan Islam yang karyanya sangat terkenal yang berjudul Muqadimah yaitu Ibnu Khaldun. Dalam tulisan ini akan dijelaskan mengenai Dekontruksi 
pemikiran Ibnu Khaldun tentang pendidikan, apa konsep dan tujuan pendidikan menurut Ibnu Khaldun dan bagaimana relevansinya pada era sekarang ini.

\section{Metode}

Dalam menyusun artikel ini, peneliti menggunakan jenis penelitian kepustakaan (library research). Yaitu serangkaian kegiatan yang berkenaan dengan pengumpulan data pustaka, membaca, mencatat serta mengolah bahan penelitian. Dan juga menggunakan pendekatan kualitatif, dimana prosedur penelitian yang menghasilkan data deskriptif berupa kata-kata tertulis atau lisan yang disampaikan dari orang-orang dan perilaku yang diamati. Karena jenis penelitian ini adalah kepustakaan, maka data- data yang diperoleh itu berupa buku-buku, dokumen, catatan, artikel dan sumber-sumber lainya dari internet yang terkait dengan permasalahan yang diangkat penulis.

\section{Hasil Dan Pembahasan}

\section{A. Kehidupan Ibnu Khaldun}

Ibnu Khaldun berasal dari Yaman Hadramaut dengan nama Khalid bin al Khottob dan tinggal di Carmona sebuah kota kecil yang terletak di antara Cordova, Sevilaa dan Granada disebelah selatan Granada. Khalid kemudian terkenal dengan Khaldun bin Usman bin Hani bin al Khottob bin Kuraib Maadi Karib bin al Haris bin Hajr. ${ }^{1}$ Ia berasal dari keluarga terpelajar dari pemimpin politik di sevilla dan pada waktu itu keilmuan dijadikan sebagai persyaratan untuk menjadi pemimpin. Pada waktu itu yang menjadi pemimpin politik di sevilla berada di tangan keluarga Khaldun dan keluarga bangsawan lainnya serta pengaruh dan kekuasaannya ada ditangan Khaldun, sedangkan kekuasaan penguasa hanya nama saja. ${ }^{2}$

\footnotetext{
${ }^{1}$ Ali Audah, Ibnu Kaldun Sebuah Pengantar (Semarang: PT. Pustaka, t.t, hlm. 1- 5.

${ }^{2}$ Fathiyyah Hasan Sulaiman, Pandangan Ibnu Khaldun Tentang Ilmu dan Pendidikan
} (Bandung: CV Diponegoro, Cet I, 1987), hlm. 5. 
Pada waktu spanyol diserbu oleh Kristen, sebelum seluruhnya jatuh ke tangan Kristen, Khaldun mengambil keputusan untuk meninggalkan sevilla dan akan menuju barat laut afrika. Para pengungsi dari spanyol ke barat laut Afrika membentuk kelompok sendiri yang disebut kelompok elit serta mereka member sumbangan yang besar terhadap perkembangan kebudayaan barat laut afrika. ${ }^{3}$ Kakek Ibnu Khaldun yang ikut mengungsi ke barat laut Afrika adalah Al Hasan bin Muhammad dan mereka menetap di sabata (ceuta) suatu kota dibarat laut afrika yang merupakan persinggahan pertama dari pengungsi yang pergi ke Spanyol.

Pada tahun 1283 ia meninggal dunia kerena dibunuh olehtentara ibnu abi umar yang membertontak terhadap bani hafs. Pada watku itu kakeknya Muhammad memegang jabatan sebagai kepala rumah tangga kerajaan dan mempunyai pengaruh yang sangat besar terhadap kerajaan karena kepribadiannya. Setelah menunaikan ibadah haji dua kali, ia pensiun dan mengabdikan dirinya untuk mengkaji studi keagamaan, sampai ia meninggal dunia pada tahun 1336 (737 H), yang pada waktu itu Ibnu Khaldun baru berusia 4 tahun. Ayahnya bernama Muhammad mengusai ilmu yang mendalam mengenai al-Qur'an dan Ilmu Fiqh gramatika dan sastra. Ia membimbing Ibnu Khaldun untuk mencintai berbagai ilmu-ilmu pengetahuan politik dan filsafat yang melahirkan suatu generasi yaitu perpaduan ulama, sarjana dan negarawan yang sungguh menakjubkan dan itulah Ibnu Khaldun. ${ }^{4}$

\section{B. Riwayat Pendidikan Ibnu Khaldun}

Namanya adalah Abu Zaid, Abdul Rahman ibnu Muhammad bin Khaldun yang lahir pada awal ramadhan 732 H (27 Mei 1332) di kota Tunis. ${ }^{5}$ Ada yang

\footnotetext{
${ }^{3}$ Ali Audah, Ibnu Kaldun Sebuah Pengantar (Semarang: PT. Pustaka, t.t, hlm5

${ }^{4}$ Ibid....11

${ }^{5}$ Ibid.... 75
} 
mengatakan ia lahir pada tanggal 1 Ramadhan 732 H (7 Mei 1332).12 Disamping nama tersebut dia memperoleh gelar tambahan yaitu waliuddin al tunisi al hadrawi. Gelar waliuddin merupakan gelar yang diberikan sewaktu dia memangku jabatan hakim (qodli) di mesir, pada masa pemerintahan sultan dzahir Burquq, salah seorang sultan Mamluk di Mesir, sedang tambahan al Hadrawi di belakang namanya bertalian dengan nama negeri asalnya itu Hadromaut, sebab seluruh keluarganya berasal dari Yaman Hadromaut. Disamping gelar dibelakang namanya masih banyak lagi nama panggilan yang menyatakan tugas dan kedudukan ilmiah dan status sosial, antara lain: al wazir, al rois, al hajib, al shadrul kabir, al ffaqihul jalil, 'allamatul ummah dan jamalul Islam wal muslimin. ${ }^{6}$

Dari nama-nama tambahan di belakang namanya nampaklah bahwa Ibnu Khaldun adalah seorang ilmuwan terkemuka pada zamannya yang telah memperoleh pengakuan dari berbagai kalangan keilmuan termasuk ilmuan non muslim. Dari sekian banyak gelar yang diperolehnya itu, tentu berdasarkan sikap pribadi dan bimbingan orangtua dan gurunya serta pengalaman-pengalaman yang diperolehnya melalui pengembaraan dan bergaul dengan bermacam macam suku bangsa dan situasi pemerintahan yang selalu silih berganti yang dihadapinya. Untuk mengetahui lebih lanjut mengenai Ibnu Khaldun tentang sikap dan pribadinya yang terbentuk melalui pengalaman belajar dari banyak guru-gurunya, jabatan dalam politik dan pemerintahan. ${ }^{7}$

Ibnu Khaldun dikenal sebagai ilmuan yang memperlakukan sejarah sebagai ilmu serta memberikan alasan-alasan untuk mendukung fakta-fakta yang terjadi. Khaldun juga dikenal sebagai ulama segala ilmu (sejarah, sosiologi, politik, ekonomi, hukum, dan agama). Pada umur 20 tahun, Ibnu Khaldun mengenyam pendidikan yang fokus belajar Tajwid, Qiroah, dan menghafal Al-Qur,an. Ia

\footnotetext{
${ }^{6}$ Ali Audah, Ibnu Kaldun Sebuah Pengantar (Semarang: Pt. Pustaka, T.T, HIm 75

7 Hamam Burhanuddin. Dekontruksi Pemikiran Ibnu Khaldun Tentang Pendidikan. Edukasi, Volume 03, Nomor 01, Juni 2015: 699-718
} 
mempelajari fikih mazhab Maliki, Hadist Rasul, dan Puisi. Ia mempelajari Hadist dari Abu 'Abd Allah Muhammad bin Jabir bin Sultan al-Qaisi al-Wadiyashi, seorang otoritas hadist terbesar dari Tunisia yang kemudian menganugerahkan ijazah kepada Ibnu Khaldun untuk mengajar bahasa dan hukum. Ibnu Khaldun juga menerima ijazah dari guru-gurunya yang lain dari sarjana-sarjana terkemuka yang mengungsi ke Tunisia.

\section{Pokok-pokok Pikiran Pendidikan Islam Ibnu Khaldun 1. Kurikulum dan Hakikat Ilmu}

Salah satu inti dari kurikulum adalah adanya materi yang merupakan bagian dari ilmu pengetahuan. Dalm hal ini, Ibnu Khaldun membagi ilmu mejadi tiga kelompok, yaitu: Al-Ulum al-Naqliyyah (pengetahuanpengetahuan penukilan), Ilmu-ilmu yang ada pada kelompok ini, menurut Ibnu Khaldun adalah ilmu-ilmu tradisional, konvensional (al-'ulum annaqliyyah al-wadh'iyyah) yang semuanya bersandar kepada informasi berdasarkan autoritas syariah yang diberikan. Misalnya, Ilmu-ilmu tafsir Qur'an dan qiraat Qur'an, Ilmu-ilmu hadis, Ilmu-ilmu fiqh dan cabangcabangnya, hukumhukum waris Fiqh, Ilmu Faraidh, Ilmu ushul fiqh dan cabang-cabangnya, dialektika dan soal-soal yang controversial, Ilmu Kalam, Ilmu Tasawuf, dan mu ta'bir mimpi. Al-Ulum al-Aqliyah (pengetahuanpengetahuan rasional), Kelompok ilmu yang kedua ini juga disebut dengan ulum al-fasafah wa al-hikmah atau ilmu-ilmu filsafat dan hikmah. Secara garis besar, ilmu-ilmu aqliyah ini dikelompokkan lagi oleh Ibnu Khaldun ke dalam 4 macam, yaitu: Ilmu logika (manthiq), Ilmu alam, atau disebut juga "fisika", Ilmu "metafisika", dan Ilmu matematika (Geometri, Aritmetika, Musika, Astronomi). Dan Ilmu-ilmu yang berkaitan dengan Bahasa Arab 
(ilmu alat); Bagi Ibnu Khaldun, sendi bahasa Arab itu ada empat, yaitu: Ilmu Nahwu, Ilmu Leksikografi, Ilmu Bayan, dan Ilmu Sastra (Adab). ${ }^{8}$

Ibnu Khaldun juga memandang bahwa ilmu pengetahuan merupakan anugerah dari Allah SWT. Meskipun ia mengklasifikasikan jenis ilmu kepada dua kelompok, naqliyah dan aqliyah, tetapi pada hakekatnya semua berasal dari Allah. Ilmu naqliyah yang bersumber dari al-Qur'an jelas merupakan kalam Allah. Sementara kelompok ilmu aqliyah yang diperoleh dengan akal pikiran juga pada hakekatnya anugerah dari Allah, terutama akal pikiran tersebut. Dengan pandangan seperti ini, maka orang yang memiliki ilmu tidak diperkenankan menyombongkan diri. Akan tetapi dengan ilmu tersebut, seseorang diharapkan akan banyak beramal dan semakin dekat kepada Allah serta mampu memberikan kontribusi yang positif kepada lingkungannya. Dari klasifikasi ilmu yang telah dibuat oleh Ibnu Khaldun tersebut, dapat diketahui dengan jelas bahwa pemikirannya tentang kurikulum (materi pendidikan) memiliki karakteristik tersendiri. Mengenai karakteristik ini, Nana Jumhana (1998: 95-97) menyebutkan setidaknya ada empat hal yang menjadi karakteristik tersebut, yaitu: Pertama, tidak adanya pemisahan antara ilmu teoritis dengan ilmu praktis. Karakteristik ini tampak ketika Ibnu Khaldun menjelaskan bahwa malakah (penguasaan) yang terbentuk dari pengajaran ilmu atau pencarian keterampilan di dalam suatu industri tidak lain adalah buah dari aktivitas "intelektual fisik" di dalam satu waktu.

Dengan demikian sesuai dengan pandangan modern yang mengatakan bahwa belajar harus melibatkan akal dan fisik secara serempak, dan belajar tidak akan sempurna jika hal ini tidak terjadi. Kedua, adanya keseimbangan antara ilmu agama dengan ilmu aqliyah. Meskipun 
dia meletakkan ilmu agama pada tempat pertama ditinjau dari segi kegunaannya bagi murid, karena dapat membentuk kepribadiannya untuk hidup dengan baik, namun dia juga meletakkan ilmu 'aqliyyah pada tempat yang tidak kurang kemuliaan dan kepentingannya dari ilmu agama. Hal itu disebabkan ilmu 'aqliyah dihasilkan dari aktivitas akal yang merupakan pemberian terbesar dari Allah swt. kepada manusia. Ketiga, berorientasi kepada anggapan bahwa tugas mengajar adalah alat terpuji untuk mencari rizki. Maka dia memasukkan tujuan baru dari pengajaran, yaitu sebagai sarana memperoleh rizki. Dengan demikian pandangannya jauh berbeda dengan tokoh pendidikan muslim sebelumnya, terutama al-Ghazali yang memandang bahwa orang yang menuntut ilmu dengan maksud menjadikannya sebagai alat mendapatkan rizki adalah suatu perbuatan tercela. Keempat, kurikulumnya berorientasi untuk menjadikan pengajaran bersifat umum, mencakup berbagai aspek ilmu pengetahuan dengan tidak mengabaikan bahasa dan logika, sebagai alatnya. Dengan demikian kurikulum diharapkan memperoleh porsiyang cukup dari pendidikan umum yang memungkinkannya untuk memperdalam studi selanjutnya yang lebih penting, dan yang hanya mungkin dapat ditekuni setelah dia memperoleh studi asasi yang cukup dalam aspek-aspek pengetahuan yang lain.

Sebagai filosof muslim, pemikiran Ibnu Khaldun sangatlah rasional dan banyak berpegang dengan logika. Meskipun corak pemikirannya dilatarbelakangi Al-Ghazali dan Ibnu Rusyd, dan bankan dituding lebih cenderung bercorak Ibnu Rusyd namun justru ia mencela konsep metafisika yang dikonsepkan oleh Ibnu Rusyd dan bahkan disni ia mampu memsintesiskan pemikiran kedua tokoh yang bertentangan tersebut, yakni 
pemikiran baru bersifat rasionalistik-sufistik. Begitu juga dalam pandangan mengenai pendidikan Islam berpijak pada pendekatan Filosofis -Empiris. ${ }^{9}$

Pendekatan ini memberikan arah baru bagi dalam pemikiran visi Pendidikan Islam secara ideal dan praktis. Sebagai ilmuan Ibnu Khaldun telah berhasil melahirkan pemikiran sintesa antara idealis dan realism. Meskipun demikian Ibnu Kahldun merupakan muslim tasawuf yang masuk didalam dunia yang berjiwa ilmiah. Hal ini bisa dilihat dalam setiap kajiannya tentang suatu keilmuan yang selalu diiringi konsep ilmiah juga dibarengi pembahasan aya-ayat Al-qur"an sebagai kajian pendukung baik pendek maupun panjang. Dalam corak pemikiran yang telah diulas secara singkat sebagai seorang ilmuan dan filosof, semua itu didukung factor sosiokultural pada masa itu yang kemudian menjadikan ia seorang ilmuan yang kahs Rasionalistik-empiristik dan sufistik. ${ }^{10}$

\section{Pemikiran Ibnu Khaldun Tentang Pendidikan}

Menurut aliran pragmatis instrumental bahwa kelebihan manusia dari makhluk lainnya terutama binatang, karena selain berkemampuan mengindera (idrak) yang ada di luar dirinya, juga manusia mempunyai kelebihan lain yakni akal pikiran. Dengan akal pikiran itu mampu melakukan apersepsi, abstraksi temuan-temuan indera dan imajinasi. Sehingga manusialah salah satu makhluk Tuhan yang pantas sebagai khalifah fil ard yang diberi tugas khusus untuk mengurus dan mengelola bumi sebagaimana mestinya, sebagaimana Allah swt berfirman dalam QS. al-Baqarah ayat 30; Ingatlah ketika Tuhanmu berfirman kepada Para Malaikat:

${ }^{9}$ Samsul Nizar,. 2002. Filsafat Pendidikan Islam: Pendekatan Historis, Teoritis Dan Praktis.: Ciputat Pers. Jakarta

10Pasiska. Epistemologi Metode Pendidikan Islam Ibnu Khaldun. El-Ghiroh. Vol. Xvii, No. 02. September 2019 
"Sesungguhnya aku hendak menjadikan seorang khalifah di muka bumi." mereka berkata: "Mengapa Engkau hendak menjadikan (khalifah) di bumi itu orang yang akan membuat kerusakan padanya dan menumpahkan darah, Padahal Kami Senantiasa bertasbih dengan memuji Engkau dan mensucikan Engkau?" Tuhan berfirman: "Sesungguhnya aku mengetahui apa yang tidak kamu ketahui."11

Ibnu Khaldun membagi kemampuan berpikir manusia menjadi tiga tingkatan yaitu; al-'aql al-tamyiz (akal pemisah) yaitu tingkat akal terbawah, karena kemampuannya hanya terbatas pada mengetahui hal-hal yang bersifat empiris inderawi. Konsep-konsep yang dihasilkan taraf berpikir tingkat ini adalah deskripsi atau penggambaran (al-tasawwurat). tujuannya adalah menghasilkan kemanfaatan bagi manusia dan menolak bahaya. Dan al-'aql al-tarbiyyi (akal eksprimental) adalah kemampuan berpikir yang menghasilkan berbagai gagasan pemikiran dan berbagai etika dalam tatanan pergaulan bersama dan hal ihwal mereka.

Kemampuan manusia untuk berpikir baru diperoleh setelah sifat kebinatangannya mencapai kesempurnaan di dalam dirinya. Hal itu dimulai dari kemampuan membedakan (tamyiz) sehingga manusia mengetahui halhal yang bermanfaat bagi dirinya dan hal-hal yang merugikan dirinya. Prinsip pendidikannya tentang pendidikan antara lain tampak pada sikapnya yang menganggap bahwa manusia berbeda dengan binatang karena kapasitas berpikirnya. Akal pikirannya memimpinnya, menciptakan kehidupan dan untuk bekerja sama dengan anggota-anggota masyarakat lainnya serta untuk menerima wahyu Tuhan yang diberikan kepada NabiNya guna kesejahteraan di dunia dan di akhirat. Manusia oleh karena makhluk yang berakal pikiran dan akal pikirannya itulah yang menjadi dasar bagi semua kegiatan belajarnya. Sudut pandangnya dalam bidang pendidikan lebih banyak bersifat pragmatis dan lebih berorientasi pada

${ }^{11}$ M. Quraish Shihab, al- Qur'an dan Maknanya, (Tanggerang: Lentera Hati, 2010), hal. 7 
aplikatif praktis. Dia mengklasifikasikan ilmu pengetahuan berdasarkan tujuan fungsionalnya,bukan berdasar nilai substansialnya atau sekuensnya semata. ${ }^{12}$

\section{Metode Pendidikan Islam}

Metode dalam pendidikan Islam adalah aspek yang penting, sebab metode merupakan faktor penentu keberhasilan dalam usaha dalam mewujudkan tujuan pendidikan. Dalam metode tentunya pendidikan akan diharapkan mampu melakukan aktivitas pembelajaran secara kreatif guna membangun respon positif dari peserta didik. Sebaik apapun ulasan materi pembelajaran yang disiapkan, jika tidak didukung dengan metode mengajar yang baik tentunya tidak akan mencapai target maksimal dalam pencapaian tujuan pendidikan. Ibnu Khaldun mengkritik para pendidik (guru) yang tidak memahami metode mengajar dengan baik, misalnya memaksa anak untuk memforsir tanaga dan pikirannya. Maka beliau menyarankan agar tidak terlalu lama memberikan materi. Ibnu Khaldun menyarankan agar tidak menggunakan metode kekerasan. Sebab, bila dididik dengan kekerasan maka akan membentuk karakter yang buruk serta dipengaruhi bayang-bayang kekerasa itu sendiri.

Dalam pandangan Ibnu Khaldun, hukum yang keras di dalam pengajaran dapat berbahaya bagi peserta didik, karena akan menyebabkan timbulnya kebiasaan buruk. Kekasaran dan kekerasan dalam pengajaran dapat mengakibatkan bahwa kekerasan itu sendiri akan menguasai jiwa dan mencegah perkembangan pribadi anak yang bersangkutan. Kekarasan membuka jalan ke arah kemalasan dan penipuan guna menghindari hukuman $^{13}$

${ }^{12}$ Abuddin Nata, Filsafat Pendidikan Islam, (Jakarta, Gaya Media Pratama, 2005), hal. 221

${ }^{13}$ Abd. Rachman, Assegaf, Aliran Pemikiran Pendidikan Islam: Hadharah Keilmuan Tokoh Klasik Sampai Modern, Jakarta: Raja Grafindo Persada, 2013 


\section{Relevansi Pemikiran Pendidikan Ibnu Khaldun dengan Pendidikan Indonesia di era Modern}

Meskipun Ibnu Khaldun hidup di abad ke-21, tetapi pemikirannya tentang pendidikan Islam tampaknya tetap aktual dan relevan untuk penerapan pendidikan Islam dalam konteks kekinian, termasuk di Indonesia. Bahkan pemikiran yang beliau kembangkan selama ini cocok dan mampu mewarnai sistem pendidikan Islam yang terjadi saat ini. Ada beberapa pemikiran dari Ibnu Khaldun yang menurut hemat penulis relevan dengan sistem pendidikan Islam Indonesia dewasa ini.; diantaranya dalam aspek tujuan pendidikan Islam, kurikulum, metode dan aspek pendidik sebagai penyelenggara proses pendidikan Islam.

\section{Tujuan Pendidikan Islam}

Konsep manusia yang dikemukakan oleh Ibnu Khaldun dengan pandangan sisdiknas memiliki relevansi. Ibnu Khaldun, yang dikutip oleh Muhammad Athiyah alAbrasyi, merumuskan tujuan pendidikan Islam dengan merujuk pada firman Allah SWT dalam QS. al- Qashash ayat 77, “ Dan carilah pada apa yang telah dianugerahkan Allah Kepadamu (kebahagiaan) negeri akhirat dan janganlah kamu lupa bagian dari (kenikmatan) duniawi". Sehingga beliau merumuskan menjadi dua macam: tujuan yang berorientasi pada ukhrawi yaitu membentuk seorang hamba agar melakukan kewajiban kepada Allah. Tujuan yang berorientasi pada duniawi yaitu membentuk manusia yang mampu menghadapi segala bentuk kebutuhan dan tantangan kehidupan.

Sementara dalam tujuan pendidikan Indonesia yang tertuang dalam Undang-Undang Sisdiknas Nomor 20 Tahun 2003 Tentang Sistem Pendidikan Nasional Bab II Pasal 3 menyatakan bahwa, pendidikan nasional berfungsi mengembangkan kemampuan dan membentuk watak serta

peradaban bangsa yang bermartabat dalam rangka mencerdaskan 
kehidupan bangsa, bertujuan untuk berkembangnya potensi peserta didik agar menjadi manusia yang beriman, bertaqwa kepada Tuhan Yang Maha Esa, berakhlak mulia, sehat, berilmu, cakap, kreatif, mandiri, dan menjadi warga negara yang demokratis serta bertanggung jawab265. Kedua, Ibnu Khaldun juga berpendapat bahwa pendidikan mendidik manusia untuk membangun kehidupan sosial. Artinya, memiliki kemampuan untuk meningkatkan taraf hidup bermasyarakat karena merupakan bagian yang tak terpisahkan dari masyarakat. Dalam hal ini, Ibnu Khaldun memberikan kontribusi bahwasanya pendidikan merupakan sarana dalam meningkatkan kemampuan seseorang untuk hidup sosial di lingkungan masyarakat yang memahami tugas dan tanggung jawabnya di masyarakat.

Begitu pula dengan tujuan pendidikan dalam sisdiknas yang tertuang dalam Undang-Undang Nomor 20 Tahun 2003 Tentang Sistem Pendidikan Nasional Bab II Pasal 3 menyatakan bahwa, tujuan pendidikan nasional adalah berkembangnya potensi peserta didik agar menjadi manusia yang beriman, bertaqwa kepada Tuhan Yang Maha Esa, berakhlak mulia, sehat, berilmu, cakap, kreatif, mandiri, dan menjadi warga negara yang demokratis serta bertanggung jawab. Dengan demikian tampak jelas adanya relevansi pemikiran Ibnu Khaldun tentang tujuan pendidikan Islam. Ibnu Khaldun mengaharapkan konsep tersebut tidak hanya bersifat teoritis belaka tetapi juga bersifat praktis sehingga mempengaruhi komponen-komponen pendidikan yang lainnya.

\section{Metode Pengajaran}

Pendidikan merupakan salah satu agen perubahan masa depan. Dengan perkembangan dunia secara global mengikuti arus modernisasi menjadikan pendidikan harus lebih aktual, dinamis dan kritis dalam merespon perkembangan tersebut. Sehingga, pendidikan Islam secara 
khusus dapat mengikuti dan berkompetisi dalam peradaban dunia modern yang terus berkembang. Dalam mewujudkannya, peran pendidik akan sangat dominan, sebab pendidik yang berinteraksi langsung dengan peserta didik. Dalam melakukan interaksi itu tentunya akan digunakan beragam cara/metode yang relevan. Berbicara tentang metode pengajaran, tampaknya akan terus menjadi bahan diskusi di beberapa instansi. Sebab, metode sangat menentukan berhasil atau tidaknya proses pendidikan yang dilakukan dalam mencapai tujuan pendidikan. Ada beberapa metode yang ditawarkan Ibnu Khaldun yang diantaranya relevan dengan sistem pendidikan yang berjalan saat ini.

\section{Pendidik}

Pendidik memang aspek penting dalam dunia pendidikan. Berhasil atau tidaknya pendidikan akan sangat dipengaruhi dari aspek pendidik. Sebab, pendidik adalah orang yang melakukan proses penyelenggaraan pendidikan di lapangan secara riil. Sebaik apapun rancangan metode dan materi pembelajaran tidak akan berarti jika tidak didukung dari aspek personal pendidikan yang memiliki kemampuan kreativitas yang memadai. Maka oleh karenanya dalam dunia pendidikan di Indonesia, setidaknya pendidik memnuhi beberapa kompetensi penting sebgai prasyarat untuk dikukuhkan sebagai tenaga pendidik yang profesional.

Kemudian, pandangan Ibnu Khaldun tentang profesi guru dan berhak mendapatkan upah yang layak, upah tersebut dimaksud sebagai sebuah perhargaan dan penghasilan untuk kebutuhan hidup pendidik tersebut. Hal itu juga relevan/sesuai dengan kebutuhan guru dewasa ini. Dalam UU No. 14 Tahun 2005 Bab IV Pasal 15 ayat 1 menyatakan bahwa, pengahsilan di atas kebutuhan hidup minimum sebagaimana dimaksud meliputi gaji pokok, tunjangan yang melekat pada gaji, serta penghasilan lain berupa tunjangan profesi, tunjangan fungsional, tunjangan khusus, dan 
maslahat tambahan yang terkait dengan tugasnya sebagai guru yang ditetapkan dengan prinsip penghargaan atas dasar prestasi. ${ }^{14}$

\section{Kesimpulan}

Tokoh ini mempunyai nama lengkap 'Abd al-Rahman ibnu Muhammad ibnu Muhammad ibnu Muhammad ibn al-Hasan ibnu Jabir ibnu Muhammad ibnu Ibrahim ibnu Khalid ibnu 'Usman ibnu Hani ibnu al-Khattab ibnu Kuraib ibnu Ma'dikarib ibnu al-Haris ibnu Wail ibnu Hujr. Ibnu Khaldun memang secara langsung tidak membicarakan pendidikan dalam kitab karangannya. Namun secara eksplisit dalam pemikiran beliau melalui kitab yang dikarangnya itu mengandung beberapa unsur penting dalam dunia pendidikan. Diantaranya menyangkut persoalan tujuan pendidikan, metode pendidikan, pendidik kurikulum pendidikan dan sebagainya.

Berdasarkan pokok pikiran yang dibentuk oleh Ibnu Khaldun bisa disimpulkan bahwa pemikirannya tentang konsep pendidikan memiliki relevansi dengan pendidikan Indonesia dewasa ini. Relevansi itu dapat terlihat pada dua hal,pertama, pemikiran Ibnu Khaldun memiliki relevansi dengan pelaksanaan pendidikan Islam yang telah ada dan sedang dilaksanakan. Kedua, pemikiran Ibnu Khaldun akan sangat relevan untuk diaktualisasikan dalam pelaksanaan pendidikan dewasa ini. Seperti yang telah dijelaskan di atas tadi, relevansi teori dari Ibnu Khaldun tersebut tentang tujuan pendidikan, kurikulum, metode, pendidik yang di dalamnya termaktub beberapa konsep memiliki relevansi atau kesesuaian dengan konsep pendidikan Indonesia yang selama ini telah dijalankan.

\section{Referensi}

${ }^{14}$ Muhammad Insan Jauhari. Konsep Pendidikan Ibnu Khaldun Dan Relevansinya Terhadap Pendidikan Di Era Modern. Jurnal Komunikasi Dan Pendidikan Islam, Volume 9, Nomor 1, Juni 2020 
Ali Audah, 2002. Ibnu Kaldun Sebuah Pengantar. Semarang: PT. Pustaka

Fathiyyah Hasan Sulaiman, , 1987. Pandangan Ibnu Khaldun Tentang Ilmu dan Pendidikan Bandung: CV Diponegoro, Cet I

Hamam Burhanuddin. Dekontruksi Pemikiran Ibnu Khaldun Tentang Pendidikan. Edukasi, Volume 03, Nomor 01, Juni 2015: 699-718

Samsul Nizar,. 2002. Filsafat Pendidikan Islam: Pendekatan Historis, Teoritis Dan Praktis.: Ciputat Pers. Jakarta

Pasiska. Epistemologi Metode Pendidikan Islam Ibnu Khaldun. El-Ghiroh. Vol. Xvii, No. 02. September2019

M. Quraish Shihab, 2010, al- Qur'an dan Maknanya, Tanggerang: Lentera Hati Abuddin Nata, 2005. Filsafat Pendidikan Islam, Jakarta, Gaya Media Pratama Muhammad Insan Jauhari. Konsep Pendidikan Ibnu Khaldun Dan Relevansinya Terhadap Pendidikan Di Era Modern. Jurnal Komunikasi Dan Pendidikan Islam, Volume 9, Nomor 1, Juni 2020 